\title{
Uji Nitrit Pada Produk Air Minum Dalam Kemasan (AMDK) Yang Beredar Dipasaran
}

\section{(Market Survey Based Nitrit Test For Bottled Drinking Water Products)}

\author{
Lutfi Amanati \\ Peneliti Balai Riset dan Standardisasi Industri \\ KEMENPERIN \\ Surabaya Indonesia \\ lutphie_a@.yahoo.com
}

\begin{abstract}
Abstrak -- Banyaknya air minum dalam kemasan yang beredar dan semakin banyaknya pencemaran kualitas air maka dilakukan penelitian pengujian nitrit pada air minum dalam kemasan . Pada penelitian ini telah dilakukan pengambilan sampel air minum dalam kemasan baik yang berada di proses produksi maupun di gudang bahan jadi. Sampel di ambil di 60 titik di jawa timur. Pengujian nitrit menggunakan SNI AMDK 01-3554-2006 secara spektrofotometri UV-Vis dengan menggunakan pereaksi N-(1-naptil) etilendiamina dihidroklorida (NEDA) melalui reaksi diazotasi. Tujuan penelitian ini adalah untuk mengetahui kadar nitirit pada AMDK yang beredar di Jawa Timur. Konsentrasi nitrit pada air minum dalam kemasan dari 60 sampel di gudang bahan jadi yang diambil di proses produksi 12 sampel yang tidak memenuhi syarat. Sedangkan dari 60 sampel yang diambil di gudang bahan baku 7 sampel tidak memenuhi syarat yaitu lebih besar dari $0.005 \mathrm{mg} / \mathrm{l}$
\end{abstract}

Kata kunci - Air minum dalam kemasan, nitrit, spektrofotometri $U V$-Vis

\begin{abstract}
-- many bottled drinking water in circulation and increased pollution of raw water then do research on the nitrite testing of bottled water In This study has been conducted sampling bottled drinking water both in the production process and in the finished material warehouse. Samples were taken in 60 points in East Java. Testing nitrite in water drinking use SNI 01-3554-2006 using $U V$-Vis spectrophotometry using reagent $N$ - (1-naptil) ethylenediamine dihydrochloride (NEDA) through reaction of diazotizing. The purpose of this study was to know content nitrit on bottled drinking water in East Java. The concentration of nitrite in drinking water in containers of 60 samples taken in the barn 12 samples was not adequate to the national tandard of drinking water. While the 60 samples taken in the warehouse of raw materials 7 samples ineligible that is, greater than $0005 \mathrm{mg} / \mathrm{l}$
\end{abstract}

Keywords - Botted Drinking Water, nitrit, spectrofotometri UVVis ,

\section{PENDAHULUAN}

Indonesia dengan sumber daya air yang cukup besar, baik air permukaan maupun air bawah permukaan merupakan karunia Tuhan yang perlu dilestarikan dari gangguan pencemaran dan kerusakan. Pada umumnya kualitas air dari suatu sumber air permukaan dapat dilihat atau diamati dari kandungan oksigen terlarutnya (DO), kebutuhan biologi akan oksigen (BOD) dan kebutuhan kimiawi akan oksigen (COD).

Pada saat ini ini banyak orang yang mengkonsumsi produk produk instan, salah satunya adalah air minum. Pada jaman dahulu masyarakat mengkonsumsi air minum dengan cara di rebus, tetapi seiringnya waktu banyak berdiri industri-industri air minum dalam kemasan. Karena itu penelitian ini bertujuan untuk mengetahui kadar nitrit dalam Air minum dalam kemasan (AMDK) yang beredar baik di proses produksi maupun dalam proses penyimpanan (gudang). Karena pada kenyataannya terdapat beberapa factor yang mempengaruhi keseimbangan oksigeen dalam air antara lain kehadiran nitrogen dalam air. Nitrit sangat berbahaya bagi manusia. Nitrit merupakan salah satu parameter kunci dari standard air minum dalam kemasan

\section{TINJAUAN PUSTAKA}

Pencemaran air minum oleh bahan bahan organik menyebabkan kadar amonia dan hidrogen sulfida meningkat. Amonia larut di dalam air dan membentuk senyawa ammonium yang cenderung akan mengikat oksigen. Dengan adanya mikroba Nitrosomonas senyawa amonium dan oksigen dapat membentuk senyawa nitrit $\mathrm{NO}_{2}$ dan dengan adanya mikroba Nitrobakter dapat membentuk senyawa nitrat $\left(\mathrm{NO}_{3}\right)$. Nitrit sangat berbahaya untuk tubuh terutama bayi di bawah umur 3 bulan, karena dapat menyebabkan methaemoglobinemia yaitu keadaan di mana nitrit akan mengikat haemoglobin $(\mathrm{Hb})$ darah dan menghalangi ikatan $\mathrm{Hb}$ dengan oksigen [1,2]. Dalam Peraturan Pemerintah No. 20 P990 dan Permenkes No.416fl990 tentang Pengendalian Air disebutkan bahwa kadar maksimum yang diperkenankan ada dalam air minum masing-masing untuk nitrat dan nitrtit adalah $10 \mathrm{mg} / \mathrm{l}$ dan $1 \mathrm{mg} / \mathrm{l}[3]$

Nitrat $\left(\mathrm{NO}_{3}\right)$ dan nitrit $\left(\mathrm{NO}_{2}\right)$ adalah ion-ion anorganik alami, yang merupakan bagian dari siklus nitrogen. Aktifitas mikroba di tanah atau air menguraikan sampah yang mengandung nitrogen organik pertama-pertama menjadi ammonia, kemudian dioksidasikan menjadi nitrit dan nitrat. Oleh karena nitrit dapat dengan mudah dioksidasikan menjadi 
nitrat, maka nitrat adalah senyawa yang paling sering ditemukan di dalam air bawah tanah maupun air yang terdapat di permukaan. Pencemaran oleh pupuk nitrogen, termasuk ammonia anhidrat seperti juga sampah organik hewan maupun manusia, dapat meningkatkan kadar nitrat di dalam air. Senyawa yang mengandung nitrat di dalam tanah biasanya larut dan dengan mudah bermigrasi dengan air bawah

tanah.

Pada daerah dimana pupuk nitrogen secara luas digunakan, sumur-sumur perumahan yang ada disana hampir pasti tercemar oleh nitrat. Pada daerah pertanian, pupuk nitrogen merupakan sumber utama pencemaran terhadap air bawah tanah yang digunakan sebagai air minum. Sumber nitrat lainnya pada air sumur adalah pencemaran dari sampah organik hewan dan rembesan dari septic tank.

Bahan makanan yang tercemar oleh nitrit ataupun bahan makanan yang diawetkan menggunakan nitrat dan nitrit dapat menyebabkan methemoglobinemia simptomatik pada anakanak. Walaupun sayuran jarang menjadi sumber keracunan akut, mereka memberi kontribusi $>70 \%$ nitrat dalam diet manusia tertentu. Kembang kol, bayam, brokoli, dan umbiumbian memiliki kandungan nitrat alami lebih banyak dari sayuran lainnya. Sisanya berasal dari air minum $(+21 \%)$ dan dari daging atau produk olahan daging $(6 \%)$ yang sering memakai natrium nitrat $\left(\mathrm{NaNO}_{3}\right)$ sebagai pengawet maupun pewarna makanan. Methemoglobinemia simptomatik telah terjadi pada anak-anak yang memakan sosis yang menggunakan nitrit dan nitrat secara berlebihan [4].

Air mineral dan air minum dalam kemasan sendiri mempunyai perbedaan. Untuk lebih jelas mengenai perbedaan air mineral, air minum dalam kemasn dan yang lainnya, Menurut SNI 01-3553-2006 adalah [5]

- Air minum dalam kemasan (AMDK) adalah air baku yang telah di proses, dikemas, dan aman diminum mencakup air mineral dan air demineral.

- Air baku adalah air yang telah memenuhi syarat kualitas air bersih sesuai peraturan yang berlaku

- Air mineral adalah air minum dalam kemasan yang mengandung mineral dalam jumlah tertentu tanpa menambahkan mineral.

- Air demineral / Air murni/ Non mineral adalah air minum dalam kemasan yang diperoleh melalui proses pemurnian seperti destilasi, seionisasi, reverse osmosis dan proses setara. [5]
Tabel 1. Persyaratan Air Minum Dalam Kemasan [5]

\begin{tabular}{|c|c|c|c|c|}
\hline No & Parameter $\mathrm{Uji}$ & Satuan & \begin{tabular}{|l|} 
Persyaratan Mutu \\
SNI 01-3553-2006
\end{tabular} & Metode \\
\hline \multirow[t]{4}{*}{1} & Keadaan : & & & \\
\hline & Bau & - & Tidak berbau & SNI 01-3554-2006 \\
\hline & Rasa & - & Normal & SNI 01-3554-2006 \\
\hline & Warna & Unit Pt Co & Maksimal 5 & SNI 01-3554-2006 \\
\hline 2 & $\mathrm{pH}$ & - & $6.0-8.5$ & SNI 01-3554-2006 \\
\hline 3 & Kekeruhan NTU & NTU & Maksimal 1.5 & SNI 01-3554-2006 \\
\hline 4 & Zat yang terlarut & $\mathrm{mg} / \mathrm{L}$ & Maksimal 500 & SNI 01-3554-2006 \\
\hline 5 & Zat Organik & $\mathrm{mg} / \mathrm{L}$ & Maksimal 1.0 & SNI 01-3554-2006 \\
\hline 6 & Nitrat sebagai NOÀ & $\mathrm{mg} / \mathrm{L}$ & Maksimal 45 & SNI 01-3554-2006 \\
\hline 7 & Nitrit sebagai $\mathrm{NO}_{i}$ & $\mathrm{mg} / \mathrm{L}$ & Maksimal 0.005 & SNI 01-3554-2006 \\
\hline 8 & Amonium (NHÁ & $\mathrm{mg} / \mathrm{L}$ & Maksimal 0.15 & SNI 01-3554-2006 \\
\hline 9 & Sulfat (SOÁ & $\mathrm{mg} / \mathrm{L}$ & Maksimal 200 & SNI 01-3554-2006 \\
\hline 10 & Klorida (Cl) & $\mathrm{mg} / \mathrm{L}$ & Maksimal 250 & SNI 01-3554-2006 \\
\hline 11 & Fuorida (F) & $\mathrm{mg} / \mathrm{L}$ & Maksimal 1 & SNI 01-3554-2006 \\
\hline 12 & Sianida $(\mathrm{CN})$ & $\mathrm{mg} / \mathrm{L}$ & Maksimal 0.05 & SNI 01-3554-2006 \\
\hline 13 & Besi (Fe) & $\mathrm{mg} / \mathrm{L}$ & Maksimal 0.1 & SNI 01-3554-2006 \\
\hline 14 & Mangan (Mn) & $\mathrm{mg} / \mathrm{L}$ & Maksimal 0.05 & SNI 01-3554-2006 \\
\hline 15 & Klor bebas $\left(\mathrm{Cl}_{\dot{ }}\right)$ & $\mathrm{mg} / \mathrm{L}$ & Maksimal 0.1 & SNI 01-3554-2006 \\
\hline 16 & Kromium (Cr) & $\mathrm{mg} / \mathrm{L}$ & Maksimal 0.05 & SNI 01-3554-2006 \\
\hline 17 & Barium (Ba) *) & $\mathrm{mg} / \mathrm{L}$ & Maksimal 0.7 & SNI 01-3554-2006 \\
\hline 18 & Boron(B) & $\mathrm{mg} / \mathrm{L}$ & Maksimal 0.3 & SNI 01-3554-2006 \\
\hline 19 & Selenium (Se) *) & $\mathrm{mg} / \mathrm{L}$ & Maksimal 0.01 & SNI 01-3554-2006 \\
\hline 20 & Cemaran logam & & & \\
\hline & Timbal $\left.(\mathrm{Pb})^{*}\right)$ & $\mathrm{mg} / \mathrm{L}$ & Maksimal 0.005 & SNI 01-3554-2006 \\
\hline & Tembaga(Cu) & $\mathrm{mg} / \mathrm{L}$ & Maksimal 0.5 & SNI 01-3554-2006 \\
\hline & Kadmium (Cd) & $\mathrm{mg} / \mathrm{L}$ & Maksimal 0.003 & SNI 01-3554-2006 \\
\hline & Raksa $(\mathrm{Hg})$ & $\mathrm{mg} / \mathrm{L}$ & Maksimal 0.001 & SNI 01-3554-2006 \\
\hline 21 & Cemaran Arsen (As) & $\mathrm{mg} / \mathrm{L}$ & Maksimal 0.01 & SNI 01-4866-1998 \\
\hline 22 & Cemaran mikroba & & & \\
\hline & ALT awal $\quad$ **) & Koloni/ $100 \mathrm{ml}$ & Maks. $1,0 \times 10 / \mathrm{Eml}$ & SNI 01-3554-2006 \\
\hline & ALT akhir $\quad{ }^{* \star \star}$ ) & Koloni/ $100 \mathrm{ml}$ & Maks. $1,0 \times 10 \phi$ & SNI 01-3554-2006 \\
\hline & Bakteri bentuk coli & APM $/ 100 \mathrm{ml}$ & $<2$ & SNI 01-2897-1992 \\
\hline & Salmonella & - & Negatip/100 ml & SNI 01-3554-2006 \\
\hline & Pseudomonas aeroginosa & Koloni/100ml & $\mathrm{Nol}$ & SNI 01-3554-2006 \\
\hline
\end{tabular}

\section{BAHAN DAN METODE}

\section{A. Bahan}

Metode penelitian dilakukan dengan observasi langsung yaitu dengan mengambil sampel di line produksi dan gudang serta pengujian laboratorium.Sampel uji adalah Air minum dalam kemasan (AMDK) baik di proses produksi maupun di gudang penyimpanan yang beredar di jawa timur. Hasil kemudian di analisis untuk menggambarkan kandungan nitrit pada Air minum dalam kemasan yang beredar.

\section{B. Metode}

\section{- Pengujian Nitrit}

Pengukuran kadar nitrit adalah berdasarkan pembentukan warna kemerahan-merahan yang terjadi bila mereaksikan nitrit dengan asam sulfanilat dan $\mathrm{N}-(1-$ naftil etilen diamin dihidroklorid) pada $\mathrm{pH} 2$ sampai $\mathrm{pH} 5.2$

Peralatan :

- Spektrofotometer sinar tunggal atau sinar ganda yang mempunyai kisaran panjang gelombang $190 \mathrm{~nm}-900 \mathrm{~nm}$ dan lebar celah $0,2 \mathrm{~nm}-2 \mathrm{~nm}$ serta telah dikalibrasi;

- Pipet volume ukuran $1,00 \mathrm{ml}, 5 \mathrm{ml}$ terkalibrasi;

- Labu ukur $50 \mathrm{ml}, 100 \mathrm{ml}$ dan terkalibrasi;

- Pipet ukur $10 \mathrm{ml}$ dan $50 \mathrm{ml}$, terkalibrasi;

- Erlenmeyer $100 \mathrm{ml}$; 
Pereaksi :

- Larutan Standar nitrit $1000 \mathrm{mg} / \mathrm{ltan}$

- Aquabidest

- Larutan Asam Sulfanilat;

Larutkan 5,0 gr sulfanilamid dengan campuran $50 \mathrm{ml} \mathrm{HCl}$ pekat dan $300 \mathrm{ml}$ air suling dalam gelas piala $500 \mathrm{ml}$.

Encerkan dengan air suling hingga volumenya menjadi 500 $\mathrm{ml}$

- Larutan Naftil Etilendiamin Dihidroklorida;

Larutkan $500 \mathrm{mg} \mathrm{N}$-(1-naftil etilendiamin dihidroklorida) dengan $100 \mathrm{ml}$ air suling dalam gelas piala $500 \mathrm{ml}$. Encerkan dengan air suling sampai volumenya mencapai $500 \mathrm{ml}$ dan simpan dalam botol berwarna gelap dan larutan ini harus diganti setiap bulan atau bila larutan berubah warna menjadi coklat tua.

\section{Cara Kerja :}

- Pembuatan Larutan Standar Baku Nitrit, $\mathrm{NO}_{2}^{-}-\mathrm{N}$

Pipet larutan standar nitrit $1000 \mathrm{mg} / \mathrm{l}$ kedalam labu ukur $100 \mathrm{ml}$ untuk memperoleh kadar nitrit sebesar 0,$05 ; 0,10$; 0,25 dan $0,50 \mathrm{mg} / \mathrm{l}$. Tambahkan air suling bebas nitrit sampai tepat tanda tera.

- Pipet $50 \mathrm{ml}$ contoh ke dalam Erlenmeyer $100 \mathrm{ml}$.

Kedalam larutan standar dan contoh tambahkan $1 \mathrm{ml}$ asam sulfanilat. Biarkan larutan tersebut bereaksi selama 2-8 menit. Tambahkan $1 \mathrm{ml}$ larutan naftil etilendiamin dihidroklorid, aduk dan biarkan paling sedikit 10 menit, tetapi tidak lebih dari 2 jam. Masukkan ke dalam kuvet spektrofotometer dan absorbennya.

Perhitungan :

Hitung kadar $\mathrm{NO}_{2}-\mathrm{N}$ dalam contoh dengan menggunakan kurva kalibrasi atau persamaan garis regresi linier[6].

\section{Verifikasi Metode Uji}

\section{- Presisi}

Pengujian nitrit air minum dalam kemasan sebanyak 6-10 kali ulangan. Kemudian Hitung konsentrasi masingmasing ulangan, presisi metode uji di hitung dengan menghitung nilai RSD (Relative Standar Deviasi) sbb : [7]

Nilai rata-rata

$(\theta)=\left(\mathrm{x}_{1}+\mathrm{x}_{2}+\ldots \ldots \ldots . . . \mathrm{x}_{\mathrm{n}}\right) / \mathrm{n}$

Standar deviasi $(s)={\sqrt{\sum_{i=1}^{n} \frac{\left[x_{1}-\theta\right]}{n-1}}}^{2}$

$\% \operatorname{RSD}=\frac{S}{\theta} \times 100 \%$

Hitung $C V_{\text {Horwitz }}=2 . e^{(1-0.5 \log c)}$
TABEL 2. PRESISI UJI NITRIT PADA AMDK

\begin{tabular}{|c|c|c|}
\hline No. & Konsentrasi (X) & $(\mathrm{X}-\mathrm{Xr})^{\wedge} 2$ \\
\hline 1 & 0.40300 & 8.1E-05 \\
\hline 2 & 0.40500 & 0.000121 \\
\hline 3 & 0.40400 & 0.0001 \\
\hline 4 & 0.40300 & $8.1 \mathrm{E}-05$ \\
\hline 5 & 0.40200 & $6.4 \mathrm{E}-05$ \\
\hline 6 & 0.38800 & 3.6E-05 \\
\hline 7 & 0.38300 & 0.000121 \\
\hline 8 & 0.38100 & 0.000169 \\
\hline 9 & 0.37700 & 0.000289 \\
\hline 10 & 0.37700 & 0.000289 \\
\hline Jumlah & 3.923 & 0.001351 \\
\hline Rata-2 (Xr) & 0.394 & \\
\hline \multicolumn{3}{|c|}{0.012120231} \\
\hline SD $=$ & $\left.V(X-X r)^{\wedge} 2 /(n-1)\right\}^{\wedge} 0.5$ & 0.012252 \\
\hline $\mathrm{CV}(\mathrm{RSD})_{\mathrm{contoh}}=$ & $\{\mathrm{SD} / \mathrm{Xr}\} * 100 \%$ & 3.109641 \\
\hline $\mathrm{CV}_{\text {horwitz }}=$ & $2^{\wedge}\left\{1-\left(0.5^{*} \operatorname{LOG}\left(\mathrm{Xr}^{*} 10^{\wedge}-6\right)\right)\right\}$ & 18.40788 \\
\hline $\mathrm{CV}$ repeatability $=$ & 2/3* CV horwitz & 12.27192 \\
\hline
\end{tabular}

- Recovery

Menguji sample misal hasilnya $\mathrm{C}_{1}$,kemudian Larutan contoh $\left(\mathrm{C}_{1}\right)+$ standar 1 di uji kadar nitritnya dan dilakukan , 3 kali pengulangan konsentrasi yang berbeda [7]. Hitung $\%$ Recovery $(\% \mathrm{R})$ dengan rumus sebagai berikut :

$$
\mathrm{R}=\frac{(\text { contoh }+s \tan d a r)-(\text { contoh })}{(s \tan d a r)} \times 100 \%
$$

TABEL 3. HASIL AKURASI NITRIT PADA AMDK

\begin{tabular}{|c|c|c|c|c|}
\hline No & Spl + spike (A) & spl (B) & $\begin{array}{c}\text { spike } \\
(\mathbf{C})\end{array}$ & $\begin{array}{c}\text { \% } \mathbf{R}= \\
(\mathbf{A}-\mathbf{B}) / \mathbf{C} \mathbf{x} \\
\mathbf{1 0 0 \%}\end{array}$ \\
\hline 1 & 0.053 & 0 & 0.05 & 106.0 \\
\hline 2 & 0.05 & 0 & 0.05 & 100.0 \\
\hline 3 & 0.046 & 0 & 0.05 & 92.0 \\
\hline 4 & 0.178 & 0 & 0.2 & 89.0 \\
\hline 5 & 0.176 & 0 & 0.2 & 88.0 \\
\hline 6 & 0.172 & 0 & 0.2 & 86.0 \\
\hline 7 & 0.403 & 0 & 0.4 & 100.8 \\
\hline 8 & 0.402 & 0 & 0.4 & 100.5 \\
\hline 9 & 0.37 & 0 & 0.4 & 92.5 \\
\hline
\end{tabular}

Verifikasi metode uji nitrit dengan metode spektrofotometri pada Air Minum Dalam Kemasan dapat diterima, bila \% Recovery berada antara $80 \%-110 \%$ [8].

\section{- Limit Deteksi}

Limit deteksi dibuat dengan cara membuat kurva kalibrasi denga konsentrasi kecil kemudian mengukur larutan blanko dengan analit terkecil yang masih memberikan respon positip Kemudian pengujian dilakukan 3 kali ulangan dan masingmasing ulangan dihitung konsentrasinya dengan 
menggunakan kurva kalibrasi diatas dan rata-ratakan hasilnyadi dapatkan standard deviasi (SD) dari 7 Kali ulangan tersebut [7].

Menghitung limit deteksi (LOD) dengan rumus sebagai berikut :

$\mathrm{LOD}=3 \mathrm{SD}$

LOD $=$ Limit of Detection

TABEL 4. HASIL LOD ANALISA NITRIT PADA AMDK $y=0.93878 x+0.01365$

\begin{tabular}{|c|r|r|r|}
\hline \multirow{2}{*}{$n$} & \multicolumn{3}{|c|}{ Blank0 Contoh + Spike (konsentrasi terendah) } \\
\cline { 2 - 4 } & \multicolumn{1}{c|}{ Absorbansi } & \multicolumn{1}{c|}{ Konsentrasi } & \multicolumn{1}{c|}{$($ X-Xr)2 } \\
\hline 1 & 0.0149 & 0.0013 & $8.1633 \mathrm{E}-08$ \\
\hline 2 & 0.0151 & 0.0015 & $7.3469 \mathrm{E}-09$ \\
\hline 3 & 0.0151 & 0.0016 & $2.0408 \mathrm{E}-10$ \\
\hline 4 & 0.0152 & 0.0016 & $2.0408 \mathrm{E}-10$ \\
\hline 5 & 0.0154 & 0.0018 & $4.5918 \mathrm{E}-08$ \\
\hline 6 & 0.0154 & 0.0019 & $9.8776 \mathrm{E}-08$ \\
\hline 7 & 0.015 & 0.0014 & $3.449 \mathrm{E}-08$ \\
\hline Jumlah & & 0.0111 & $2.6857 \mathrm{E}-07$ \\
Rata-rata & & 0.001585714 & $3.8367 \mathrm{E}-08$ \\
SD & & 0.00021157 & \\
\hline
\end{tabular}

$\begin{array}{lr}\mathrm{LOD}= & 3 \mathrm{SD} \\ \mathrm{LOD}= & 0.00063471\end{array}$

\section{HASIL DAN PEMBAHASAN}

1. Nitrit pada AMDK di Proses produksi

Sampel air minum dalam kemasan diambil di bagian proses produksi di berbagai pabrik air minum dalam kemasan yang berada di Jawa timur. Dari 60 sampel yang diuji, ditarik kesimpulan bahwa terdapat 12 produk yang kadar nitritnya melampau batas maksimum yaitu 0,005 $\mathrm{mg} / \mathrm{l}$, hal ini dapat di t pada Gambar 1 grafik kandungan nitrit pada AMDK di Produksi. Sedangan yang lainnya memenuhi syarat mutu SNI 01-3553-2006 yaitu di bawah $0.005 \mathrm{mg} / \mathrm{l}$. . Hasil uji yang negatip atau tidak terdeteksi dinyatakan dengan nilai LOD dari nitrit yaitu $<0.000634$

TABEL 5 . HASIL UJI NITRIT DALAM PRODUKSI

\begin{tabular}{|c|c|c|c|}
\hline No & Nitrit (mg/l) & No & $\begin{array}{c}\text { Nitrit } \\
(\mathbf{m g} / \mathbf{l})\end{array}$ \\
\hline 1 & 0.0264 & 31 & $<0.000634$ \\
\hline 2 & 0.0448 & 32 & $<0.000634$ \\
\hline 3 & 0.0057 & 33 & $<0.000634$ \\
\hline 4 & 0.0176 & 34 & $<0.000634$ \\
\hline 5 & 0.0198 & 35 & $<0.000634$ \\
\hline 6 & 0.02 & 36 & $<0.000634$ \\
\hline 7 & 0.013 & 37 & $<0.000634$ \\
\hline 8 & 0.025 & 38 & $<0.000634$ \\
\hline
\end{tabular}

\begin{tabular}{|c|c|c|c|}
\hline No & Nitrit (mg/l) & No & $\begin{array}{l}\text { Nitrit } \\
(\mathrm{mg} / \mathrm{l})\end{array}$ \\
\hline 9 & 0.0154 & 39 & $<0.000634$ \\
\hline 10 & 0.026 & 40 & $<0.000634$ \\
\hline 11 & 0.018 & 41 & $<0.000634$ \\
\hline 12 & 0.0161 & 42 & $<0.000634$ \\
\hline 13 & 0.001 & 43 & $<0.000634$ \\
\hline 14 & 0.0012 & 44 & $<0.000634$ \\
\hline 15 & 0.0021 & 45 & $<0.000634$ \\
\hline 16 & 0.0036 & 46 & $<0.000634$ \\
\hline 17 & 0.0031 & 47 & $<0.000634$ \\
\hline 18 & 0.0016 & 48 & $<0.000634$ \\
\hline 19 & 0.0015 & 49 & $<0.000634$ \\
\hline 20 & 0.0005 & 50 & $<0.000634$ \\
\hline 21 & 0.005 & 51 & $<0.000634$ \\
\hline 22 & 0.0045 & 52 & $<0.000634$ \\
\hline 23 & 0.003 & 53 & $<0.000634$ \\
\hline 24 & 0.00095 & 54 & $<0.000634$ \\
\hline 25 & 0.001 & 55 & $<0.000634$ \\
\hline 26 & 0.00215 & 56 & $<0.000634$ \\
\hline 27 & 0.0036 & 57 & $<0.000634$ \\
\hline 28 & 0.0007 & 58 & $<0.000634$ \\
\hline 29 & 0.0012 & 59 & $<0.000634$ \\
\hline 30 & $<0.000639$ & 60 & $<0.000634$ \\
\hline
\end{tabular}

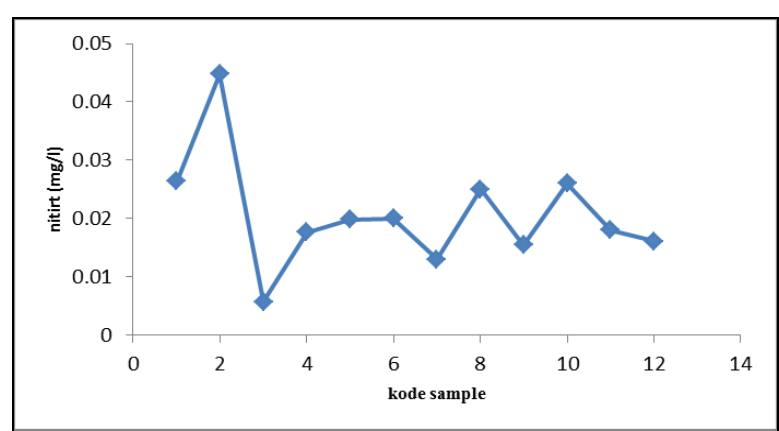

Gambar 1. Grafik Kandungan Nitrit pada AMDK di Produksi

2. Nitrit pada AMDk di Gudang

TABEL 6. HASIL UJi NiTRIT Di GUDANG

\begin{tabular}{|c|c|c|c|}
\hline No & Nitrit $(\mathbf{m g} / \mathbf{l})$ & No & Nitrit $(\mathrm{mg} / \mathbf{l})$ \\
\hline 1 & 0.0373 & 31 & $<0.000634$ \\
\hline 2 & 0.0061 & 32 & $<0.000634$ \\
\hline 3 & 0.0076 & 33 & $<0.000634$ \\
\hline 4 & 0.0175 & 34 & $<0.000634$ \\
\hline 5 & 0.016 & 35 & $<0.000634$ \\
\hline 6 & 0.006 & 36 & $<0.000634$ \\
\hline
\end{tabular}




\begin{tabular}{|c|c|c|c|}
\hline No & Nitrit (mg/l) & No & Nitrit (mg/l) \\
\hline 7 & 0.01 & 37 & $<0.000634$ \\
\hline 8 & 0.00425 & 38 & $<0.000634$ \\
\hline 9 & 0.00475 & 39 & $<0.000634$ \\
\hline 10 & 0.00125 & 40 & $<0.000634$ \\
\hline 11 & 0.0026 & 41 & $<0.000634$ \\
\hline 12 & 0.00315 & 42 & $<0.000634$ \\
\hline 13 & 0.00205 & 43 & $<0.000634$ \\
\hline 14 & 0.0025 & 44 & $<0.000634$ \\
\hline 15 & 0.0022 & 45 & $<0.000634$ \\
\hline 16 & 0.00195 & 46 & $<0.000634$ \\
\hline 17 & 0.0013 & 47 & $<0.000634$ \\
\hline 18 & 0.00025 & 48 & $<0.000634$ \\
\hline 19 & 0.0023 & 49 & $<0.000634$ \\
\hline 20 & 0.0015 & 50 & $<0.000634$ \\
\hline 21 & 0.0005 & 51 & $<0.000634$ \\
\hline 22 & 0.001 & 52 & $<0.000634$ \\
\hline 23 & $<0.000639$ & 53 & $<0.000634$ \\
\hline 24 & $<0.000639$ & 54 & $<0.000634$ \\
\hline 25 & $<0.000639$ & 55 & $<0.000634$ \\
\hline 26 & $<0.000639$ & 56 & $<0.000634$ \\
\hline 27 & $<0.000639$ & 57 & $<0.000634$ \\
\hline 28 & $<0.000639$ & 58 & $<0.000634$ \\
\hline 29 & $<0.000639$ & 59 & $<0.000634$ \\
\hline 30 & $<0.000639$ & 60 & $<0.000634$ \\
\hline
\end{tabular}

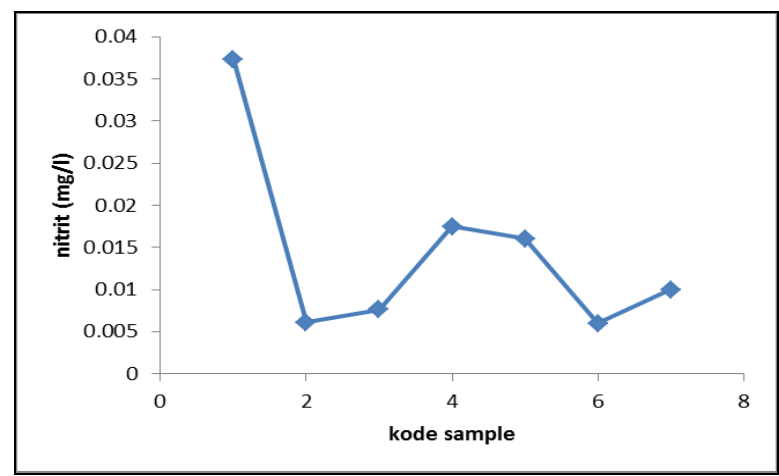

Gambar 2. Kurva kandungan Nitrit pada AMDK di gudang

Dari 60 sampel yang di ambil di berbagai gudang industri AMDK di Jawa Timur terdapat 7 produk AMDK dalam gudang yang tidak memenuhi syarat yaitu di atas $0.005 \mathrm{mg} / \mathrm{l}$.

Dari pengambilan sampel air minum dalam kemasan baik di proses produksi maupun di gudang masih banyak di temukan kandungan nitrit yang melampaui batas maksimal dari syarat mutu AMDK. Salah satu faktor yaitu pengambilan bahan baku yang telah tercemar.Meskipun air merupakan sumber alam terbarukan air akan dengan mudah terkontaminasi terhadap pencemaran yang terjadi baik udara maupun daratan. Nitrit sendiri dapat berasal dari senyawa nitrogen yang berasal dari sisa pemupukan. Limbah rumah tangga juga dapat mencemari air. Jadi jika pabrik Air minum dalam kemasan bahan bakunya tercemar limbah rumah tangga akan berpengaruh degan tingginya kandungan nitrit. Tingginya kadar nitrit di wilayah das dikarenakan aliran sungai membawa limbah, baik limbah pertanian, domestik maupun industri, sehingga air bahan baku yang letaknya dekat dengan daerah aliran sungai juga berpotensi dengan meningkatnya jumlah nitrit yang di hasilkan pada produksi Air Minum Dalam kemasan.

Persenyawaan - persenyawaan nitrogen yang terdapat dalam tanah dapat dibagi dalam tiga kelompok, yaitu:

a) Nitrogen yang ada sebagai ion-ion nitrat dan amonium, yang merupakan bagian sangat kecil dari seluruh nitrogen yang ada, namun merupakan sumber dari nitrogen bagi tanaman-tanaman

b) Nitrogen yang ada dalam persenyawaan, seringkali disebut persenyawaan nitrogen yang dapat dinitrifikasikan, yang cepat terurai untuk menghasilkan ion-ion nitrat atau amonium.

c) Nitrogen yang terdapat dalam persenyawaan yang dengan lambat terurai oleh mikroflora tanah

Nitrogen total adalah jumlah atau kadar keseluruhan nitrogen yang terdapat dalam limbah cair atau sampel, air permukaan dan lainnya. Analisis air limbah terhadap nitrogen total meliputi berbagai nitrogen yang berbeda-beda yaitu amoniak, nitrit dan nitrat. Hubungan yang timbul diantara berbagai bentuk campuran nitrogen dan perobahan-perobahan yang terjadi dalam alam pada umumnya digambarkan dengan "siklus nitrogen". Didalam air limbah kebanyakan dari nitrogen itu pada dasarnya terdapat dalam bentuk organik atau nitrogen protein dan amoniak. Setingkat demi setingkat nitrogen organik itu dirobah menjadi nitrogen amoniak, dalam kondisi-kondisi aerobik, oksidasi dari amoniak menjadi nitrit dan nitrat terjadi sesuai waktunya[8].

\section{KESIMPULAN}

Dari hasil penelitian dapat disimpulkan bahwa air minum dalam kemasan yang beredar di jawa timur

- Dari 60 sampel yang berasal dari produksi terdapat 12 sampel mengandung nitrit yang melampai batas maksimum

- Dari 60 sampel yang berasal di gudang produksi terdapat 7 sampel mengandung nitrit yang melampai batas maksimum.Hal ini dimungkinkan tercemarnya bahan baku air minum dalam kemasan. Atau terjadi pencemaran udara di pabrik yang membuat proses produksi nya terkontaminasi

\section{UCAPAN TERIMA KASIH}

Ucapkan terima kasih ditujukan kepada Baristand Industri Surabaya sebagai tempat pengujian. 


\section{DAFTAR PUSTAKA}

[1] Lubis, A dkk ,1987. "Amonium dalam Air Sumur Penduduk". Buletin Penelitian Kesehatan, Volume 15

[2] Brooks, D \& Irina ,1979. Nitrates and Bacterial Distribution in Rural Domestic Water Supplies.Water Research Vo1.13, Pergamon Press Great Britain

[3] Pemerintah RI ,1990. "Peraturan Pemerintah No.20,Tentang Pengendalian dan Pencemaran Air",Jakarta.

[4] http://dokterharry.com/20/07/02/21/keracunan nitrit-nitrat, diakses tanggal 7 november 2016

[5] BSN,SNI 01-3553-2006 Air Minum Dalam Kemasan,Jakarta
[6] BSN, SNI 01-3554-2006 Cara Uji Air MInum Dalam kemasan, Jakarata

[7] AOAC, 2002, Requirment for Single Laboratory Validation of Chemicals Methods

[8] Mahida, 1981, Water Pollution and Dissossal of waste Water on Land. Mc Graw Hill. Publishing Companny Limited Environmental.

[9] Euracheam guide, 2014,'The Fitness For Purpose of Analytical Methods a Laboratory Guide to Method Validation and Related Topic, Second edition 